\title{
Effects of butter from mountain-pasture grazing cows on risk markers of the metabolic syndrome compared with conventional Danish butter: a randomized controlled study
}

Louise B Werner $^{1 *}$, Lars I Hellgren², Marianne Raff', Søren K Jensen³, Rikke A Petersen', Tue Drachmann² and Tine Tholstrup ${ }^{1}$

\begin{abstract}
Background: There is considerable interest in dairy products from low-input systems, such as mountain-pasture grazing cows, because these products are believed to be healthier than products from high-input conventional systems. This may be due to a higher content of bioactive components, such as phytanic acid, a PPAR-agonist derived from chlorophyll. However, the effects of such products on human health have been poorly investigated.

Objective: To compare the effect of milk-fat from mountain-pasture grazing cows $(G)$ and conventionally fed cows (C) on risk markers of the metabolic syndrome.

Design: In a double-blind, randomized, 12-week, parallel intervention study, 38 healthy subjects replaced part of their habitual dietary fat intake with $39 \mathrm{~g}$ fat from test butter made from milk from mountain-pasture grazing cows or from cows fed conventional winter fodder. Glucose-tolerance and circulating risk markers were analysed before and after the intervention.
\end{abstract}

Results: No differences in blood lipids, lipoproteins, hsCRP, insulin, glucose or glucose-tolerance were observed. Interestingly, strong correlations between phytanic acid at baseline and total $(P<0.0001)$ and LDL cholesterol ( $\mathrm{P}=0.0001)$ were observed.

Conclusions: Lack of effects on blood lipids and inflammation indicates that dairy products from mountain-pasture grazing cows are not healthier than products from high-input conventional systems. Considering the strong correlation between LDL cholesterol and phytanic acid at baseline, it may be suggested that phytanic acid increases total and LDL cholesterol.

Trial registration: ClinicalTrials.gov, NCT01343589

Keywords: Dairy-fat, Low-input system, Phytanic acid, LDL cholesterol, Oral glucose tolerance test

\footnotetext{
* Correspondence: Ibw@life.ku.dk

${ }^{1}$ Department of Nutrition, Exercise and Sports, Faculty of Sciences, University of Copenhagen, Frederiksberg 1958, Denmark

Full list of author information is available at the end of the article
} 


\section{Background}

Increased consumer awareness of the link between diet and health has led to research focused on altering the fatty acid (FA) composition of cows' milk to achieve a FA profile consistent with public health recommendations. However, as modification of the FA content of milk fat in dairy cows is affected significantly by the extensive metabolism of lipids that occurs in the rumen, it is important to understand the interrelationship between dietary supply of lipids, rumen fermentation, and mammary synthesis of milk fat. Important targets include reducing the amount of long-chain saturated fatty acids (SFA's) such as C12:0-C16:0, enhancing oleic acid to reduce cardiovascular risk, and generally increasing concentrations of mono- and poly-unsaturated fatty acid (MUFA and PUFA) [1-10].

It is well known that the FA composition of milk fat is markedly influenced by the feed given to the dairy cows [11-14]. The addition of forage, especially fresh grass, to fodder has been found to enhance the proportion of unsaturated FAs in milk fat [15-17], and to elevate the concentration of the $c-9, t-11$ isomer of conjugated linoleic acid (CLA) $[17,18]$. Unlike the $c-10, t-12$ isomer of CLA, which in animal models has proved to be a biologically active FA with beneficial effects on diseases such as cancer, diabetes, and obesity [19-21], the $c-9, t-11$ CLA appears to be neutral [22-27]. However, the markedly higher intake of chlorophyll-containing green fodder in grazing cows also results in a high phytanic acid content in milk from these cows $[28,29]$. Phytanic acid may be an interesting, though so far overlooked, bioactive FA with potential positive effects on metabolic function. Phytanic acid (3,7,11,15-tetramethyl hexadecanoic acid) is a multi-branched FA with reported retinoid X receptor (RXR) and peroxisome proliferator activated receptor- $\alpha$ (PPAR- $\alpha$ ) agonist activity [30-33]. It has been suggested that, due to its reported RXR and PPAR- $\alpha$ agonist activity and its ability to induce glucose uptake in hepatocytes, phytanic acid may prevent metabolic dysfunctions related to the development of metabolic syndrome [34].

The purpose of this study was to investigate the effects on risk markers of cardiovascular diseases (CVD) and type-2 diabetes in healthy humans of a diet containing milk delivered from mountain-pasture grazing cows from Norway (G) with that of a diet containing milk fat of typical Danish composition (C). Although, modification of the dairy cows' diet has been extensively studied, only very few human dietary intervention studies have examined the effect of these modified dairy products on CVD risk. In addition, the actual effects on human health of milk from pasture-grazing cows and conventional Danish milk have been poorly investigated. Since no data exists on the effects of intake of phytanic acid in a normal diet, we have also paid particular attention on the potential effects of this FA.

\section{Subjects and methods Study design}

We conducted a 12-week, controlled, double-blind, randomized, parallel intervention study. Participants were provided with the test diets that substituted part of their daily diet and replaced approximately 15 percent of energy $(E \%)$ of their daily fat intake. Participants were stratified according to baseline blood glucose level, gender, and waist circumference, into two random treatment groups receiving either the $\mathrm{G}$ diet or the $\mathrm{C}$ diet.

\section{Subjects}

Subjects ranged in the age from 50 to 70 years old, and were recruited for the study through ads placed in local newspapers. The baseline characteristics of the 38 subjects who completed the study are given in Table 1. Exclusion criteria were: BMI $>35 \mathrm{~kg} / \mathrm{m}^{2}$, current or previous chronic disease, regular use of medication, or drug and alcohol abuse. All participants were apparently healthy as indicated by a medical and lifestyle questionnaire. They all agreed to refrain from taking any dietary supplements, from donating blood two months before and during the study, and from taking any medication that might interfere with study measurements. All subjects were instructed to maintain the same level of physical activity throughout the study. Subjects completed a three-day dietary record in order to provide information about dietary intake during the intervention. This was done before the intervention and after six weeks of intervention. We found it relevant to evaluate the diet after six weeks to gain information about dietary intake during the intervention. Two weekdays and one Saturday/Sunday were included in the dietary record to take into account any differences in nutrient intake during weekdays and the weekend. After they had delivered their first dietary record, participants were given feedback and advice on how they could decrease fat intake during the intervention period. This was achieved by guidance from our dietician. Collection of the test food as well as follow-up and weighing every second week took place at Department of Nutrition, Exercise and Sports. The subjects were also weighed before and after the intervention. In the event of weight gain, the participants were weighed each week and received advice from our dietician on how to maintain a stable weight. After four and eight weeks of intervention, the participants were interviewed about their well-being, physical activity level and diet to make sure they were adhering to the test diet and maintained the same weight and physical activity level. In addition, participants were supplied with recipes to provide inspiration on how the test diet could 
Table 1 Baseline characteristics for the 38 healthy subjects participating in the 12 week intervention ${ }^{1}$

\begin{tabular}{lll}
\hline & Grazing $(\boldsymbol{n}=\mathbf{2 0})$ & Conventional (n=18) \\
\hline Women, $(n, \%)$ & $13,65 \%$ & $10,55.6 \%$ \\
Age, $(y)$ & $61.9 \pm 4.9(52-69)$ & $60.7 \pm 5.9(50-69)$ \\
Height, $(\mathrm{cm})$ & $170.5 \pm 8.4(158-187)$ & $173.2 \pm 7.5(159.8-188)$ \\
Weight, $(\mathrm{kg})$ & $73.6 \pm 8.4(56.3-93)$ & $79.9 \pm 15.5(61.35-122.6)$ \\
BMI, $(\mathrm{kg} / \mathrm{m})$ & $25.4 \pm 2.7(20.81-30.55)$ & $26.5 \pm 3.6(21.22-34.69)$ \\
Total cholesterol, $(\mathrm{mmol} / \mathrm{L})$ & $5.8 \pm 1.15(3.95-7.53)$ & $5.5 \pm 0.86(3.98-7)$ \\
LDL cholesterol, $(\mathrm{mmol} / \mathrm{L})$ & $3.3 \pm 0.83(1.46-4.53)$ & $3.3 \pm 0.59(2.45-4.21)$ \\
HDL cholesterol, $(\mathrm{mmol} / \mathrm{L})$ & $1.5 \pm 0.29(1.02-2.06)$ & $1.3 \pm 0.31(0.75-1.73)$ \\
Triacylglycerol, $(\mathrm{mmol} / \mathrm{L})$ & $1.2 \pm 0.46(0.76-2.62)$ & $1.3 \pm 0.59(0.73-2.74)$ \\
hsCRP, $(\mathrm{mg} / \mathrm{L})$ & $1.2 \pm 1.46(0.05-5.42)$ & $1.0 \pm 0.93(0.05-3.11)$ \\
Insulin, $(\mathrm{pmol} / \mathrm{L})$ & $30.6 \pm 20.05(7.2-90.75)$ & $41.4 \pm 35.04(7.2-127)$ \\
C-peptide, $(\mathrm{pmol} / \mathrm{L})$ & $566.2 \pm 224.03(349.5-1065.5)$ & $611.8 \pm 287.82(298-1299.5)$ \\
Glucose, $(\mathrm{mmol} / \mathrm{L})$ & $5.6 \pm 0.51(5.02-7.14)$ & $5.7 \pm 0.47(5.14-6.57)$ \\
Phytanic acid, $(\mu \mathrm{M})$ & $3.0 \pm 0.69(1.98-4.76)$ & $3.0 \pm 0.61(2.3-4.28)$ \\
\hline
\end{tabular}

${ }^{1}$ Values are mean \pm SD; range in parentheses. $h s C P R$ high sensitive C-reactive protein, Grazing milk from grazing cows, Conventional milk from conventionally fed cows.

be consumed. To keep track of compliance with, and potential deviations from, the study guidelines, subjects were asked to keep a log book in which they recorded on a daily basis any illness, unusual activities, and failure to consume the test diet.

Dietary intake was estimated using Dankost 3000 dietary assessment software (Dankost, Copenhagen, Denmark). Mean habitual energy intakes before the intervention were 8.6 MJ/d (range: 5.6-15.8 MJ/d); 33.5\% (24.2-48.2\%) of energy was from fat; $16.3 \%$ (11.6-22.8\%) was from protein; and $45.7 \%(30-58.3 \%)$ was from carbohydrates. Carbohydrate intake in the $\mathrm{G}$ group $(43.86 \pm 5.47 \mathrm{E} \%)$ was reported to be lower than in the $\mathrm{C}$ group $(47.84 \pm 5.27$ $\mathrm{E} \%)(\mathrm{p}=0.029)$ when expressed as $\mathrm{E} \%$, but not when expressed as $\mathrm{g} / \mathrm{d}$. There were no other differences in habitual dietary intake between the two groups. The protocol and aims of the study were fully explained (orally and in writing) to the participants, who subsequently gave written informed consent. The Scientific Ethics Committee for Copenhagen and Frederiksberg approved the research protocol (H-B-2009-052).

\section{Production of test milk}

Milk fat for the human study was derived from milk from pasture-grazing cows (Norwegian red cattle breed) or conventionally fed Danish cows (Holstein-Friesian breed). The two types of milk produced differed in FA composition. The markedly higher intake of chlorophyllcontaining green fodder of the grazing cows resulted in a high phytanic acid content in milk compared with the conventional Danish milk. The milk from grazing cows was produced by 104 cows from seven farms. It was collected in August late in the grazing-season, as it was assumed that the effects of grazing would be strongest when the cows had been grazing all summer. The conventional Danish milk was provided by Arla Food amba (Viby J, Denmark) and originated from 47 farms. It was collected in October when the cows were kept indoors and fed conventional winter fodder. Cattle feeding routines were traditional, and farmers selected fodder ingredients and made their own mixtures. Conventional Danish milk cattle fodder consists of a mixture of corn silage (35\%), wheat-barley silage (25\%), clover grass silage $(20 \%)$, soybean meal or rapeseed cake $(10 \%)$, and a small proportion of molasses or beet pellets, straw, vitamins and minerals. Milk from the grazing cows was transported to Tine BA (Oslo, Norway) where the fat was processed into butter.

\section{Diets and test fats}

The test butter had different FA compositions (Table 2). The cholesterol-raising saturated fatty acids, lauric, myristic and palmitic acid, constituted $20 \%$ less of the total FAs in the G butter than the C butter (C12:0; C14:0 and C:16:0) (36.4 vs. 45.4 wt\%). The G butter also had a $26 \%$ higher content of stearic acid (C18:0) (15.1 vs. $11.1 \mathrm{wt} \%)$, $32 \%$ higher content of trans-vacceninc acid (C18:1 t-11) (2.5 vs. $1.7 \mathrm{wt} \%), 17 \%$ higher content of oleic acid (C18:1 c-9) (25.8 vs. $21.5 \mathrm{wt} \%)$, and $33 \%$ higher content of $\alpha$ linolenic acid (C18:3 n-3) (0.9 vs. 0.6 wt\%) compared with $C$ butter. Furthermore, the $n-6 / n-3$ ratio was $45 \%$ lower in the G butter (2.9 vs. $1.6 \mathrm{wt} \%$ ) compared with $\mathrm{C}$ butter. The butter was incorporated into buns. The buns were made in one batch and provided by the Department of Nutrition, Exercise and Sports in Copenhagen. During the intervention period, subjects were requested 
Table 2 Fatty acid composition of the test butter from mountain-pasture grazing cows and from conventionally fed cows

\begin{tabular}{|c|c|c|}
\hline & \multicolumn{2}{|c|}{$\%$ fatty acid of total fatty acid } \\
\hline & Grazing & Conventional \\
\hline & \multicolumn{2}{|c|}{$\% w t$} \\
\hline C4:0 & 1.0 & 0.8 \\
\hline C6:0 & 1.3 & 1.4 \\
\hline $\mathrm{C} 8: 0$ & 1.0 & 1.1 \\
\hline C10:0 & 2.2 & 2.8 \\
\hline C12:0 & 2.6 & 3.4 \\
\hline C14:0 & 9.4 & 11.0 \\
\hline C $14: 1$ & 0.7 & 1.0 \\
\hline C15:0 & 0.9 & 1.1 \\
\hline C16:0 & 24.4 & 31.0 \\
\hline C16:1 n-7 & 1.2 & 1.6 \\
\hline C20:0 (phytanic acid) & 0.4 & 0.2 \\
\hline C17:0 & 0.6 & 0.5 \\
\hline C17:1 & 0.2 & 0.2 \\
\hline C18:0 & 15.1 & 11.1 \\
\hline C18:1 t-11 & 2.5 & 1.7 \\
\hline C18:1 n-9 & 25.8 & 21.5 \\
\hline C18:1 n-7 & 0.4 & 0.9 \\
\hline$c-9 t-11 \mathrm{CLA}$ & 0.7 & 0.6 \\
\hline C18:2 n-6 & 1.5 & 1.8 \\
\hline C18:3 n-3 & 0.9 & 0.6 \\
\hline n-6:n-3 ration & 1.6 & 2.9 \\
\hline Total SFA & 58.9 & 64.4 \\
\hline Total UFA & 33.9 & 30.0 \\
\hline Total MUFA & 30.8 & 27.0 \\
\hline Total PUFA & 3.2 & 3.0 \\
\hline
\end{tabular}

to replace part of their daily diet with three buns. The buns contained $3.5 \mathrm{MJ}$ of energy, with $7.5 \mathrm{E} \%$ from protein, $56 \mathrm{E} \%$ from carbohydrates, and $36.4 \mathrm{E} \%$ from fat. All buns contained $13 \mathrm{~g}$ of butter, which yielded a fat intake from the test diet of $39 \mathrm{~g}$ a day $(15 \mathrm{MJ})$.

\section{Compliance}

We used the concentration of pentadecanoic acid (C15:0) in plasma as an indicator of milk fat intake, and thus of compliance, because $\mathrm{C} 15: 0$ in serum is considered as a valid marker for intake of milk fat in humans [35-37]. In addition, dietary records and log books were used to reinforce the dietary advice and strengthen compliance, and the results of the last records were used in the calculation of dietary changes during the study. A participant was considered compliant when $>90 \%$ of the supplied buns had been eaten.

\section{Blood sampling and analysis}

Blood samples were taken in duplicates on two consecutive days, before the intervention period and at the end of the intervention, from fasting subjects after $10 \mathrm{mi}-$ nutes of supine rest. The values from each sample set were averaged. In addition to fasting for 12 hours, participants were asked to refrain from smoking 12 hours prior to the blood sampling and to refrain from performing any extreme sport 36 hours prior to taking the sample. Furthermore, they were asked not to drink alcohol or take medicine 24 hours prior to the blood sampling. Blood for FA analysis was collected in tubes containing EDTA, which were kept on ice, and the samples were centrifuged at $4^{\circ} \mathrm{C}$ and $2200 \times$ g for $15 \mathrm{~min}$. All samples were stored at $-80^{\circ} \mathrm{C}$ until they were analysed. All samples were analyzed at the Department of Human Nutrition, except the FA analyses, which were performed at the Technical University of Denmark.

\section{Blood lipids}

We assessed serum LDL and HDL cholesterol by enzymatic colorimetric procedure (ABX Pentra LDL Direct $\mathrm{CP}$ and $\mathrm{ABX}$ Pentra HDL Direct $\mathrm{CP}$ respectively) on ABX Pentra 400 Chemistry Analyzer (HORIBA ABX, Montpellier, France). Total cholesterol was assessed and analyzed by enzymatic photometric procedure (CHODPAP from ABX Pentra Cholesterol CP) on ABX Pentra 400 Chemistry Analyzer (HORIBA ABX, Montpellier, France). The concentration of triacylglycerol (TAG) was assessed and analyzed by enzymatic colorimetric procedure (ABX Pentra Triglycerides CP) on ABX Pentra 400 Chemistry Analyzer (HORIBA ABX, Montpellier, France). The inter assay coefficients of variation (CV\%) for total, LDL and HDL cholesterol, and TAG were 1.9\%, 3.3\%, $2.8 \%$ and $4.2 \%$, respectively. Intra assay CV\% for total, LDL and HDL cholesterol, and TAG were $0.9 \%, 0.9 \%$, $1.2 \%$ and $2.6 \%$ respectively.

\section{Fatty acid analysis in lipids and test fats}

Total lipids were extracted and analyzed from blood plasma samples as described by Tholstrup et al. [38] but using TAG C19:0 as an internal standard. For lipidextraction from the buns, three buns were homogenized in a kitchen blender, and three samples were randomly taken from the homogenate. The bun lipids were extracted according to the method of Folch [39], while preparation of fatty acid methyl esters (FAME) was performed as described earlier [38]. The response factor was calculated for methyl esters of phytanic acid and short-chained fatty acid, based on the response of palmitic acid methyl ester (C16:0). The butter FAME were separated on a 60-m Supelco SP-2380 column (SigmaAldrich AS, Brøndby, Denmark) in a HP 6890 gas Chromatograph (GC) in split mode using $\mathrm{He}$ as carrier gas. 
GC settings were: Injector temperature $260^{\circ} \mathrm{C}$, split ratio 1:20, carrier flow $1.2 \mathrm{~mL} / \mathrm{min}$, detector temperature $300^{\circ} \mathrm{C}$, air flow in detector $300,0 \mathrm{~mL} / \mathrm{min}$, hydrogen flow $35 \mathrm{~mL} / \mathrm{min}$. FAME were separated using a temperature program starting at $50^{\circ} \mathrm{C}$ and gradually increasing it to $160^{\circ} \mathrm{C}$ at a rate of $15^{\circ} \mathrm{C} / \mathrm{min}$; this temperature was kept for $0 \mathrm{~min}$, after which the temperature was increasedto $182^{\circ} \mathrm{C}$ at a rate of $1^{\circ} \mathrm{C} / \mathrm{min}$. The temperature was then raised to $200^{\circ} \mathrm{C}$ at a rate of $10^{\circ} \mathrm{C} / \mathrm{min}$, and the oven was kept at $200^{\circ} \mathrm{C}$ for $15 \mathrm{~min}$ before the temperature was increased to $225^{\circ} \mathrm{C}$. The final temperature was kept for $12 \mathrm{~min}$ (total runtime $61.97 \mathrm{~min}$ ). FAME was identified with authentic standards.

\section{Hs-C-reactive protein}

Blood for analysis of high sensitive C-reactive protein ( $h s \mathrm{CRP}$ ) was collected into dry tubes; samples were subsequently centrifuged at $2200 \times \mathrm{g}$ for $15 \mathrm{~min}$ at $20^{\circ} \mathrm{C}$. Serum was stored at $-80^{\circ} \mathrm{C}$ until the samples were analysed. The CRP concentrations were measured using latex immunoturbidimetry ( $\mathrm{ABX}$ Pentra CRP $\mathrm{CP}$ ) on ABX Pentra 400 Chemistry Analyzer (HORIBA ABX, Montpellier, France). The detection limit was $0.1 \mathrm{mg} / \mathrm{L}$. The inter and intra assay CV\% was $3.4 \%$ and $3.6 \%$, respectively.

\section{Insulin, C-peptide and glucose}

Blood for analysis of insulin and C-peptide was collected in dry tubes, whereas the blood samples for glucose were collected in tubes with fluoride citrate; for both serum and plasma preparation the samples were centrifuged at $2200 \times \mathrm{g}$ for $15 \mathrm{~min}$ at $20^{\circ} \mathrm{C}$ after coagulation. The samples were stored at $-80^{\circ} \mathrm{C}$ until analysis. Insulin and Cpeptide concentrations were measured in serum with a chemiluminescent immunometric assay on DPC Immulite 1000 (Siemens Medical Solutions Diagnostics, USA). Glucose concentrations were measured in plasma and analyzed by enzymatic colorimetric procedure (ABX Pentra Glucose HK CP) on ABX Pentra 400 Clinical Chemistry Analyzer (HORIBA ABX, Montpellier, France). The inter assay CV\% for insulin, C-peptid and glucose was 5.1\%, $4.3 \%$ and $1.7 \%$, respectively. The intra assay CV\% for insulin, C-peptid and glucose was $2.7 \%, 1.9 \%$ and $1.1 \%$.

\section{Oral glucose tolerance test}

A standard $75 \mathrm{~g}$ OGTT was administered at baseline and after 12 weeks of the study, with blood sampled for glucose and C-peptide at 0, 15, 30, 60, 90, 120 and 180 minutes [40]. Three-hour C-peptide and glucose areas under the curve (AUC) were calculated from the OGTT data, in millimol per minute per liter for glucose, and picomol per minute per liter for $\mathrm{C}$-peptide. Glucose and $\mathrm{C}$-peptide AUCs are the sum of the area of each time segment by $\mathrm{C}$-peptide or glucose concentration. C-peptide
AUC is an approximate measure of C-peptide secretion in response to a standard oral glucose load.

\section{Statistical analysis}

For both diet treatments, baseline characteristics were summarized by means of averages, standard deviations and minimum/maximum values. Pearson correlation coefficients with corresponding $\mathrm{p}$ values for testing whether or not the correlation is 0 were calculated between baseline values. The outcome variables total cholesterol, LDL, HDL, TAG, hsCRP, insulin, C-peptide, glucose and phytanic acid were analyzed using an analysis of covariance (ANCOVA) model including the treatments (the explanatory variable of interest) and adjusting for differences between groups by including the baseline level as well as the relevant covariates age, gender, smoker and weight, which may be possible confounders when evaluating blood parameters. The treatment effect was evaluated by means of an F-test. Treatment differences were reported in terms of estimated mean levels with corresponding standard errors.

Analysis of the OGTT data was carried out using a linear mixed ANCOVA including the interaction between time and diet treatment in order to assess if time modified the effect of the diets during the three-hour period of OGTT. Period effects as well as covariates adjusting for group differences in age and BMI were included in the model. Random effects were included to capture between-subject variation. The time course of the estimated treatment effects for both diets was shown graphically with corresponding standard errors. An approximate F-test was used to evaluate the diet-time interaction and, if non-significant, another approximate F-test was used to evaluate if there was a time-independent diet effect. In addition, diet effects in glucose AUC and C-peptide AUC were assessed using ANCOVA, adjusting for the baseline AUC.

For all models validation was based on graphical assessment of residual plots and normal probability plots. In the event departures were detected, the outcome variables in question were transformed using the logarithm transformation.

$\mathrm{P}$ values were evaluated at a $5 \%$ significant level. The analyses were carried out using PROC MIXED procedure in Statistical Analysis System (SAS), version 9.1 (SAS Institute, Cary, NC).

\section{Results}

\section{Compliance}

There was no difference in plasma C15:0 after the intervention, and the average increase in C15:0 from baseline was around $20 \%$ in both groups, which indicates the consumption of a similar amount of dairy products in both groups during the intervention (data not shown). 
Counting the number of buns eaten showed a mean compliance of $99.18 \pm 1.98 \%$ in all groups together and of $99.37 \pm 1.75 \%$ and $98.96 \pm 2.23 \%$ in the $G$ and $C$ group, respectively. The number of buns not eaten did not differ between the groups $(\mathrm{p}=0.54)$.

\section{Dietary intake and body weight}

Both groups had a minor weight gain during the intervention, $(0.89 \pm 1.39$ and $0.93 \pm 0.78 \mathrm{~kg}$ for $\mathrm{G}$ and $\mathrm{C}$, respectively), but the weight gain did not differ between the groups when expressed either as $\mathrm{kg}$ body weight $(\mathrm{p}=0.80)$ or BMI $(\mathrm{p}=0.55)$. A dietician evaluated all dietary records. One record from the G group was incomplete and therefore excluded from the statistical analysis. The energy and macronutrient content in the participants' daily diet during the intervention were calculated from the dietary records (Table 3). The distribution (\% energy) of protein $(\mathrm{p}=0.89)$, carbohydrates $(\mathrm{p}=0.69)$, and total fat $(\mathrm{p}=0.40)$ did not differ between the two groups.

\section{Blood samples}

We found strong correlations between plasma phytanic acid at baseline and both total $\left(\mathrm{r}^{2}=0.42, \mathrm{p}<0.0001\right)$ and LDL cholesterol $\left(\mathrm{r}^{2}=0.35, \mathrm{p}=0.0001\right)$. The correlation between the known marker of dairy-fat intake, plasma C15:0 and both total cholesterol and LDL cholesterol was weaker $\left(\mathrm{r}^{2}=0.14, \mathrm{p}=0.02\right.$ and $\mathrm{r}^{2}=0.11, \mathrm{p}=0.04$, respectively), although there was a strong correlation between plasma C15:0 and phytanic acid $\left(\mathrm{r}^{2}=0.44, \mathrm{p}<0.0001\right)$ (Table 4).

TAG, hsCRP, insulin, glucose, C-peptide AUC, and glucose AUC required logarithm transformation. No significant differences were observed between $\mathrm{G}$ and $\mathrm{C}$ diet in serum total cholesterol $(\mathrm{p}=0.38), \mathrm{LDL}$ cholesterol $(\mathrm{p}=0.55)$, HDL cholesterol $(\mathrm{p}=0.51)$, TAG $(\mathrm{p}=0.36)$, hsCRP $(\mathrm{p}=0.54)$, insulin $(\mathrm{p}=0.60)$, C-peptide $(\mathrm{p}=0.91)$, plasma glucose $(\mathrm{p}=0.63)$ or plasma phytanic acid $(\mathrm{p}=0.15)$ (Table 5$)$. Analysis of the OGTT data revealed neither a significant treatment-time interaction nor a significant treatment

\begin{tabular}{|c|c|c|}
\hline$\%$ of energy & Grazing $(n=19)$ & Conventional $(n=18)$ \\
\hline Protein & $14.3 \pm 0.4$ & $14.3 \pm 0.4$ \\
\hline Carbohydrates & $47.5 \pm 1.3$ & $46.7 \pm 1.3$ \\
\hline Total Fat & $34.0 \pm 0.9$ & $35.1 \pm 0.9$ \\
\hline Saturated FAs & $16.0 \pm 0.7$ & $15.8 \pm 0.7$ \\
\hline Monounsaturated FAs & $10.2 \pm 0.4$ & $10.6 \pm 0.4$ \\
\hline Polyunsaturated FAs & $4.0 \pm 0.2$ & $3.6 \pm 0.2$ \\
\hline
\end{tabular}

${ }^{1}$ All values are estimated means \pm SE. FAs Fatty acids, Grazing milk from grazing cows, Conventional milk from conventionally fed cows. Values were obtained from 3-day weighed food records. One dietary record was incomplete and therefore excluded from the statistical analysis. No significant differences between the two groups were found (ANCOVA). effect for glucose $(\mathrm{p}=0.52$ and $\mathrm{p}=0.27$, respectively) and for C-peptid ( $\mathrm{p}=0.43$ and $\mathrm{p}=0.98$, respectively) (Figure 1 ). There was no significant difference between the AUCs for either glucose $(\mathrm{p}=0.89)$ or $\mathrm{C}$-peptide $(\mathrm{p}=0.65)$ after the test diets (Figure 1).

There were no significant differences between groups in the erythrocyte FA composition (data not shown).

\section{Discussion}

This study was designed to compare the effects of butter produced from milk from mountain-pasture grazing cows with conventional Danish butter on risk markers of CVD and type-2 diabetes. There were no differences between diets with regard to effect on the metabolic parameters or on $h s \mathrm{CRP}$.

Despite the fact that the cholesterol-raising SFAs were decreased with $20 \%$ ( 45.4 to $36.4 \%$ of total FAs) in the $\mathrm{G}$ diet, this did not lead to lower plasma total and LDL cholesterol concentrations. This is in agreement with results from a study by Tholstrup et al. where the cholesterol-raising SFAs, especially palmitic acid, was replaced with mainly oleic and stearic acid [41]. In contrast, Noakes et al. found that consumption of modified dairy products produced through the substitution of cholesterol-raising SFAs with oleic and linoleic acid, significantly reduced total- and LDL cholesterol with $4.3 \%$ and $5.3 \%$, respectively [42]. This study reported a substantially higher change in PUFA (8 g/100 g FA), which is known to lower plasma LDL cholesterol more than do MUFA [43,44], and may be the main reason for the LDL cholesterol lowering effect [42]. This is supported by another study, which reported a decrease plasma total-and LDL cholesterol by consuming a similar modified butter with a high increase in PUFA (6.5 g/100 g FA) [45]. In addition, a combination of a relatively lower SFA and substantially higher linoleic and oleic acid in Noakes et al. [42] compared with our study could explain why the hypocholesterolemic effects of oleic and linoleic acid were successfully "expressed".

A minor increase in ruminant trans FA (rTFA) was a side effect of manipulating the cattle fodder. A study by Tholstrup et al. [46] observed that the consumption of rTFA-enriched butter $(3.6 \mathrm{~g} / \mathrm{d})$ lowered total and HDL cholesterol by $6 \%$ and $9 \%$ respectively, compared with butter low in rTFA and high in SFA. However, the authors concluded that these effects may have been partly attributable to the higher MUFA and lower SFA content in the rTFA-enriched butter, rather than to the effects of rTFA alone. Two recent clinical studies found an increase in plasma LDL cholesterol in conjunction with high daily rTFA intakes: $10-12 \mathrm{~g} / \mathrm{d}$, representing 3.6-5\% of energy [47,48]. However, an intake of $10-12 \mathrm{~g} / \mathrm{d}$ rTFA/d is very high in practical terms. The concentration of rTFA in dairy products exists in quantities that 
Table 4 Pearson's correlations coefficients between baseline variables

\begin{tabular}{|c|c|c|c|c|c|c|c|c|c|}
\hline & Phyt & HDL & LDL & Total CH & Glucose & Insulin & hsCRP & TAG & C15:0 \\
\hline Phyt & 1.0 & 0.24 & $0.6^{1}$ & $0.65^{1}$ & 0.16 & 0.01 & 0.28 & 0.29 & $0.67^{1}$ \\
\hline $\mathrm{HDL}$ & & 1.0 & 0.25 & $0.54^{4}$ & $-0.36^{4}$ & $-0.45^{4}$ & -0.27 & $-0.46^{4}$ & 0.11 \\
\hline LDL & & & 1.0 & $0.93^{4}$ & -0.14 & -0.11 & 0.16 & 0.21 & $0.34^{2}$ \\
\hline Total CH & & & & 1.0 & -0.16 & -0.2 & 0.07 & 0.15 & $0.38^{3}$ \\
\hline Glucose & & & & & 1.0 & $0.40^{4}$ & $0.49^{4}$ & $0.59^{1}$ & $0.41^{4}$ \\
\hline Insulin & & & & & & 1.0 & 0.12 & $0.46^{4}$ & -0.03 \\
\hline hsCRP & & & & & & & 1.0 & $0.46^{4}$ & $0.36^{4}$ \\
\hline TAG & & & & & & & & 1.0 & $0.33^{4}$ \\
\hline C15:0 & & & & & & & & & 1.0 \\
\hline
\end{tabular}

hsCRP high sensitive C-reactive protein, TAG Triacylglycerol, $\mathrm{CH}$ cholesterol, Phyt Phytanic acid.

$\mathrm{C} 15: 0$, Plasma pentadecanoic acid. $\mathrm{n}=38$. ${ }^{1}$ Significantly correlated $P \leq 0.0001 .{ }^{2}$ Significantly correlated $P=0.04$.

${ }^{3}$ Significantly correlated $P=0.02 .{ }^{4}$ Significantly correlated $P<0.05$.

are too small to have any effect. Thus, it is unlikely that the slight difference in trans FA in this study may have affected the results.

The intake of fresh grass also slightly elevated the concentration of CLA in the G diet, as expected from earlier studies $[17,18]$. CLA has been reported to reduce aortic atherosclerosis in animal studies [49,50]. However, human study failed to find any effect of milk CLA on cholesterol. One study in which the CLA content was enriched by rumen technology to provide $1.42 \mathrm{~g} / \mathrm{d}$ of c- 9 , $\mathrm{t}-11$ CLA in dairy products failed to affect LDL cholesterol level [27], which is in line with results from another study with a daily intake of $4.22 \mathrm{~g}$ milk CLA [23]. In addition, it is unlikely that the slight difference in CLA and the lower concentration of CLA in the current study may have affected the results.

The markedly higher intake of chlorophyll-containing green fodder in grazing cows also resulted in a high phytanic acid content in the milk. In a previous study conducted by our group [51], we found a significant increase in plasma phytanic acid in both groups, verifying

Table 5 Effects of the 12-week dietary intervention

\begin{tabular}{lll}
\hline & Grazing $(\boldsymbol{n = 2 0 )}$ & Conventional $(\boldsymbol{n = 1 8})$ \\
\hline Total cholesterol, $(\mathrm{mmo} / \mathrm{L})$ & $5.9 \pm 0.10$ & $5.8 \pm 0.11$ \\
LDL cholesterol, $(\mathrm{mmo} / \mathrm{L})$ & $3.4 \pm 0.09$ & $3.3 \pm 0.09$ \\
$\mathrm{HDL}$ cholesterol, $(\mathrm{mmo} / \mathrm{L})$ & $1.5 \pm 0.04$ & $1.4 \pm 0.04$ \\
Triacylglycerol, $(\mathrm{mmo} / \mathrm{L})$ & $1.2 \pm 1.08$ & $1.1 \pm 1.09$ \\
hsCRP, $(\mathrm{mg} / \mathrm{L})$ & $0.8 \pm 1.36$ & $0.6 \pm 1.41$ \\
Insulin, $(\mathrm{pmol} / \mathrm{L})$ & $32.0 \pm 1.11$ & $30.0 \pm 1.12$ \\
C-peptide, $(\mathrm{pmol} / \mathrm{L})$ & $586.1 \pm 1.05$ & $582.1 \pm 1.05$ \\
Glucose, $(\mathrm{mmo} / \mathrm{L})$ & $5.6 \pm 1.01$ & $5.7 \pm 1.02$ \\
Phytanic acid, $(\mu \mathrm{M})$ & $3.6 \pm 0.17$ & $3.3 \pm 0.18$ \\
\hline
\end{tabular}

$\overline{\text { All values are means } \pm \mathrm{SE} \text {. } h s C R P \text { high sensitive C-reactive protein, Grazing milk }}$ from grazing cows, Conventional milk from conventionally fed cows. No significant differences between the two diet groups were found (ANCOVA).

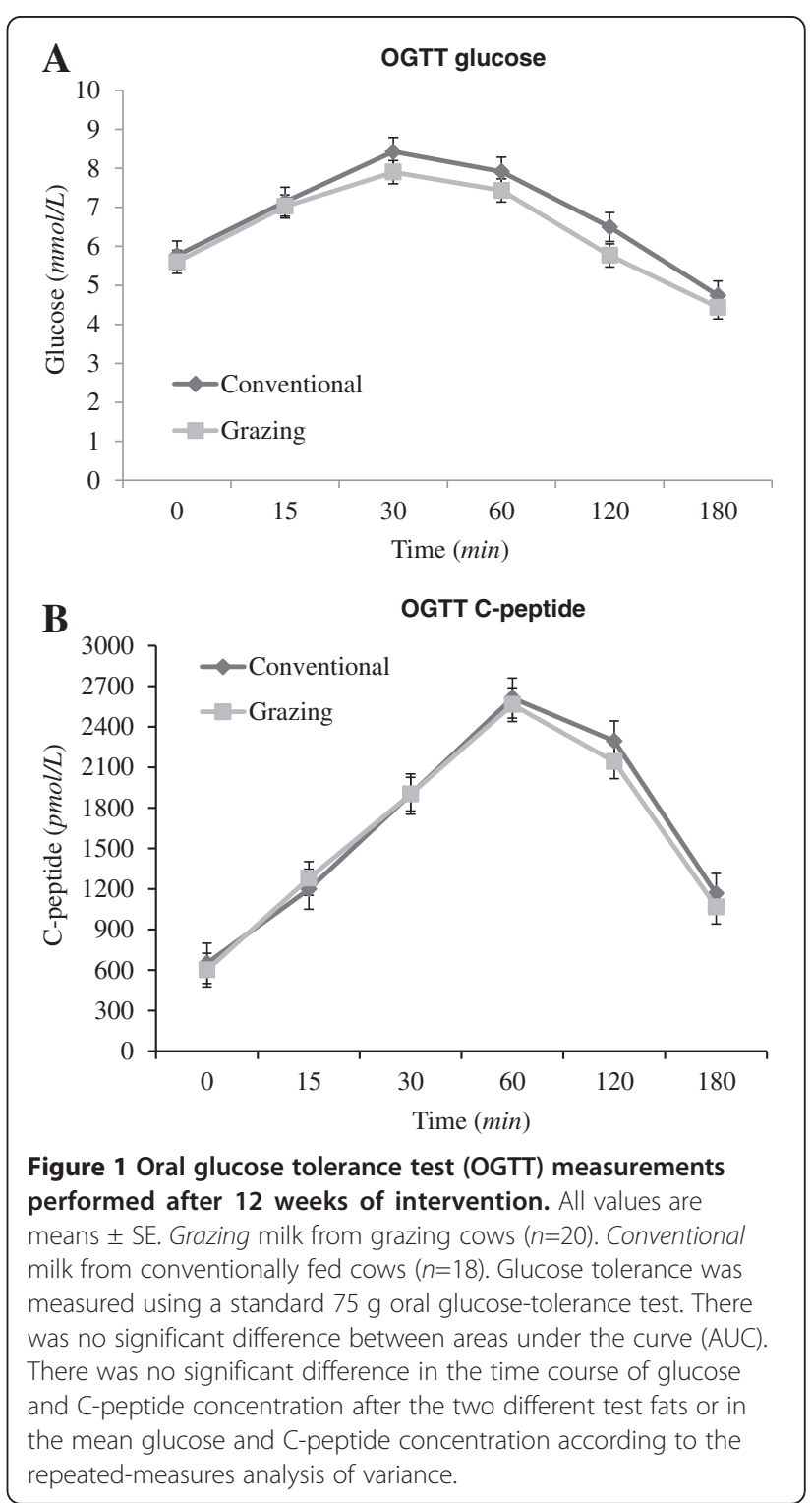


that intake of dairy products with relatively low concentrations of phytanic acid increase circulating phytanic acid concentration. This finding seems to be in agreement with observations made in this study. In the present study we found surprisingly strong correlations between phytanic acid at baseline, total cholesterol $\left(\mathrm{r}^{2}=0.42, \quad \mathrm{p}<0.0001\right)$ and LDL cholesterol $\left(\mathrm{r}^{2}=0.35\right.$, $\mathrm{p}=0.0001$ ). It seems likely that the baseline phytanic acid concentration reflects habitual dairy fat intake, which means that the strong correlations could be due to the hypercholesterolemic effect of dairy fat. This interpretation is supported by the fact that plasma phytanic acid and plasma C15:0 correspond very strongly at baseline $\left(\mathrm{r}^{2}=0.44, \mathrm{p}<0.0001\right)$. However, the correlations between plasma $\mathrm{C} 15: 0$ and both total cholesterol $\left(\mathrm{r}^{2}=0.14\right.$, $\mathrm{p}=0.02)$ and LDL cholesterol $\left(\mathrm{r}^{2}=0.11, \mathrm{p}=0.04\right)$ were substantially weaker than those observed for phytanic acid. This suggests that phytanic acid increases LDL cholesterol beyond levels that can be explained solely from dairy fat intake, indicating that phytanic acid may have specific LDL cholesterol rising effects.

We observed no differences in effects on glucose or insulin concentration between the groups. Prior to the present study, the available literature supported the hypothesis that phytanic acid might have preventive effects on metabolic dysfunctions related to the development of the metabolic syndrome [30-33]. In particular the RXRactivating ability of phytanic acid is of interest, since RXR is activated by concentrations at the same level as the phytanic acid concentrations reached in plasma in this study (21). It has been shown that drugs that activate RXR and PPAR- $\alpha$ have a marked impact on whole body metabolism and act as insulin-sensitizers or as hyperlipidemic agents [52,53], while it is not clear to what extent dietary changes in natural agonist concentrations are of physiological importance in humans.

In the current study, milk fat from mountain-pasture grazing cows which represents summer whole milk with a SFA:MUFA:PUFA proportion of 59:31:3 was more similar to conventional milk FA composition of 64:27:3 than predicted. In addition, the FA composition of conventional milk FA in the current study was more consistent with consumer perceptions of a healthy diet and with public health recommendations compared to conventional milk from 1998 with the composition of 75:22:4 [41]. This could be due to a higher amount of grass-based products in the cows' feed, and could explain why no effect is observed in the current study.

The strengths of our study include its controlled and randomized design, the long intervention period, followup of dietary compliance during the study, and the use of a validated dietary marker to monitor the dairy-fat intake. The study was also designed to investigate dietary changes caused by an increased intake of dairy products in a realistic setting, and the plasma phytanic acid concentration in this study population occurred in a concentration which has physiological relevance as a modulator of RXR-activity. Among the limitations were the relatively high intakes of butter during the intervention. Also breed of the cows may have played a role; however there is no evidence that FA composition is differently influenced by breed per se. The health effect of milk from pasture grazing cows should be further investigated. Furthermore, it could be interesting to elucidate the association between phytanic acid and the PPAR- $\alpha$ activity to better prove the effects of phytanic acid on plasma cholesterol.

\section{Conclusion}

Lack of effects on blood lipids and inflammation indicates that dairy products from mountain-pasture grazing cows are not healthier than products from high-input conventional systems. Considering the strong correlation between LDL cholesterol and phytanic acid at baseline, it may be suggested that phytanic acid increases total and LDL cholesterol. Additional studies are necessary to clarify the effect of phytanic acid on risk markers of the metabolic syndrome.

\section{Abbreviations}

FA: Fatty acid; SFA: Long-chain saturated fatty acid; MUFA: Monounsaturated fatty acid; PUFA: Polyunsaturated fatty acid; CLA: Conjugated linoleic acid; RXR: Retinoid X receptor; PPAR- $a$ : Peroxisome proliferatoractivated receptora; CVD: Cardiovascular diseases; OGTT: Oral glucose tolerance test; C15:0: Pentadecanoic acid; TAG: Triacylglycerol; CV: Coefficient of variation; hsCRP: High sensitive C-reactive protein; AUC: Area under the curve; SAS: Statistical Analysis System; rTFA: ruminant trans fatty acid.

\section{Competing interests}

The authors declare that they have no competing interests.

\section{Authors' contributions}

LBW: Conducted research, performed statistical analyses and drafted the original paper. $\mathrm{LIH}$ : Developed the initial ideas, analyzed and interpretated data and edited paper. MR: Conducted research. SKJ: Provided milk for the project. RAP: Carried out the practical work with the human study. TD: Analyzed data. TT: Developed the initial ideas, designed the study and was study project leader, interpreted results and participated in the writing of the paper. All authors have read and approved the final manuscript.

\section{Acknowledgements}

We acknowledge the financial support from the Strategic Research Council of Denmark, The Danish Dairy Research Foundation, Danish Cattle Federation and Arla Foods amba (Viby J, Denmark). We thank our Norwegian colleagues for their significant contributions to this study. Thus, Nutrition Manager Anne Sofie Biong at TINE R\&D Centre (Oslo, Norway), delivered efficiently the wanted quality of butter from pasture-grazing cows produced under controlled conditions by Professor Roger Abrahamsen from the Department of Chemistry, Biotechnology and Food Science, Norwegian University of Life Sciences. We thank the staff of the organic experimental farm at Aarhus University and Research Center Foulum, for assistance with advice and analyses of test butter. We also thank Secretary Tina Cuthbertson for efficient language editing of the final paper and the laboratory technicians at the Department of Nutrition, Exercise and Sports and at DTU Systemsbiology for technical assistance. We thank associate professor Christian Ritz for excellent statistical advice. We are also very grateful to our dietician Hanne Jensen and to the staff of the metabolic kitchen at Department of Nutrition, Exercise and sports. 


\section{Author details}

'Department of Nutrition, Exercise and Sports, Faculty of Sciences, University of Copenhagen, Frederiksberg 1958, Denmark. ${ }^{2}$ Center for Biological Sequence Analysis, DTU Systems Biology, Technical University of Denmark 2800 Lyngby, Denmark. ${ }^{3}$ Department of Animal Health and Bioscience, Faculty of Agricultural Sciences, Aarhus University, 8830 Tjele, Denmark.

Received: 1 March 2013 Accepted: 28 June 2013

Published: 10 July 2013

\section{References}

1. Bonanome A, Grundy SM: Effect of dietary stearic acid on plasma cholesterol and lipoprotein levels. N Engl J Med 1988, 318:1244-1248.

2. Denke MA, Grundy SM: Comparison of effects of lauric acid and palmitic acid on plasma lipids and lipoproteins. Am J Clin Nutr 1992, 56:895-898.

3. Grundy SM, Florentin L, Nix D, Whelan MF: Comparison of monounsaturated fatty acids and carbohydrates for reducing raised levels of plasma cholesterol in man. Am J Clin Nutr 1988, 47:965-969.

4. Mensink RP, Katan MB: Effect of a diet enriched with monounsaturated or polyunsaturated fatty acids on levels of low-density and high-density lipoprotein cholesterol in healthy women and men. N Engl J Med 1989, 321:436-441.

5. Mensink RP, Katan MB: Effect of dietary fatty acids on serum lipids and lipoproteins. A meta-analysis of 27 trials. Arterioscler Thromb 1992, 12:911-919.

6. Temme EH, Mensink RP, Hornstra G: Comparison of the effects of diets enriched in lauric, palmitic, or oleic acids on serum lipids and lipoproteins in healthy women and men. Am J Clin Nutr 1996, 63:897-903.

7. Tholstrup T, Marckmann P, Jespersen J, Sandstrom B: Fat high in stearic acid favorably affects blood lipids and factor VII coagulant activity in comparison with fats high in palmitic acid or high in myristic and lauric acids. Am J Clin Nutr 1994, 59:371-377.

8. Tholstrup T, Marckmann P, Jespersen J, Vessby B, Jart A, Sandstrom B: Effect on blood lipids, coagulation, and fibrinolysis of a fat high in myristic acid and a fat high in palmitic acid. Am J Clin Nutr 1994, 60:919-925.

9. Zock PL, de Vries JH, Katan MB: Impact of myristic acid versus palmitic acid on serum lipid and lipoprotein levels in healthy women and men. Arterioscler Thromb 1994, 14:567-575.

10. Yu S, Derr J, Etherton TD, Kris-Etherton PM: Plasma cholesterol-predictive equations demonstrate that stearic acid is neutral and monounsaturated fatty acids are hypocholesterolemic. Am J Clin Nutr 1995, 61:1129-1139.

11. Lock AL, Bauman DE: Modifying milk fat composition of dairy cows to enhance fatty acids beneficial to human health. Lipids 2004, 39:1197-1206

12. Jenkins TC, McGuire MA: Major advances in nutrition: impact on milk composition. J Dairy Sci 2006, 89:1302-1310.

13. Grummer RR: Effect of feed on the composition of milk fat. J Dairy Sci 1991, 74:3244-3257.

14. Dewhurst RJ, Fisher WJ, Tweed JK, Wilkins RJ: Comparison of grass and legume silages for milk production. 1. Production responses with different levels of concentrate. J Dairy Sci 2003, 86:2598-2611.

15. Schroeder GF, Delahoy JE, Vidaurreta I, Bargo F, Gagliostro GA, Muller LD: Milk fatty acid composition of cows fed a total mixed ration or pasture plus concentrates replacing corn with fat. J Dairy Sci 2003, 86:3237-3248.

16. Couvreur S, Hurtaud C, Lopez C, Delaby L, Peyraud JL: The linear relationship between the proportion of fresh grass in the cow diet, milk fatty acid composition, and butter properties. J Dairy Sci 2006 89:1956-1969.

17. Bargo F, Delahoy JE, Schroeder GF, Baxter JH, Muller L: Supplementing total mixed rations with pasture increase the content og conjugated linoleic acid in milk. Anim Feed Sci Technol 2006, 131:226-240.

18. Kraft J, Collomb M, Mockel P, Sieber R, Jahreis G: Differences in CLA isomer distribution of cow's milk lipids. Lipids 2003, 38:657-664.

19. Ryder JW, Portocarrero CP, Song XM, Cui L, Yu M, Combatsiaris T, et al: Isomer-specific antidiabetic properties of conjugated linoleic acid. Improved glucose tolerance, skeletal muscle insulin action, and UCP-2 gene expression. Diabetes 2001, 50:1149-1157.

20. Ip C, Jiang C, Thompson HJ, Scimeca JA: Retention of conjugated linoleic acid in the mammary gland is associated with tumor inhibition during the post-initiation phase of carcinogenesis. Carcinogenesis 1997 18:755-759.
21. Houseknecht KL, Vanden Heuvel JP, Moya-Camarena SY, Portocarrero CP, Peck LW, Nickel KP, et al: Dietary conjugated linoleic acid normalizes impaired glucose tolerance in the Zucker diabetic fatty fa/fa rat. Biochem Biophys Res Commun 1998, 244:678-682.

22. Brouwer IA, Wanders AJ, Katan MB: Effect of animal and industrial trans fatty acids on HDL and LDL cholesterol levels in humans-a quantitative review. PLoS One 2010, 5:e9434.

23. Desroches S, Chouinard PY, Galibois I, Corneau L, Delisle J, Lamarche B, et al: Lack of effect of dietary conjugated linoleic acids naturally incorporated into butter on the lipid profile and body composition of overweight and obese men. Am J Clin Nutr 2005, 82:309-319.

24. Raff M, Tholstrup T, Basu S, Nonboe P, Sorensen MT, Straarup EM: A diet rich in conjugated linoleic acid and butter increases lipid peroxidation but does not affect atherosclerotic, inflammatory, or diabetic risk markers in healthy young men. J Nutr 2008, 138:509-514

25. Sluijs I, Plantinga Y, de Roos B, Mennen LI, Bots ML: Dietary supplementation with cis-9,trans-11 conjugated linoleic acid and aortic stiffness in overweight and obese adults. Am J Clin Nutr 2010, 91:175-183.

26. Tholstrup T, Raff M, Straarup EM, Lund P, Basu S, Bruun JM: An oil mixture with trans-10, cis-12 conjugated linoleic acid increases markers of inflammation and in vivo lipid peroxidation compared with cis-9, trans11 conjugated linoleic acid in postmenopausal women. J Nutr 2008 138:1445-1451.

27. Tricon S, Burdge GC, Jones EL, Russell JJ, El-Khazen S, Moretti E, et al: Effects of dairy products naturally enriched with cis-9, trans-11 conjugated linoleic acid on the blood lipid profile in healthy middle-aged men. Am J Clin Nutr 2006, 83:744-753.

28. Leiber F, Kreuzer M, Nigg D, Wettstein HR, Scheeder MR: A study on the causes for the elevated n-3 fatty acids in cows' milk of alpine origin. Lipids 2005, 40:191-202.

29. Lough AK: The phytanic acid content of the lipids of bovine tissues and milk. Lipids 1977, 12:115-119.

30. Ellinghaus P, Wolfrum C, Assmann G, Spener F, Seedorf U: Phytanic acid activates the peroxisome proliferator-activated receptor alpha (PPARalpha) in sterol carrier protein 2-/ sterol carrier protein x-deficient mice. J Biol Chem 1999, 274:2766-2772.

31. Heim M, Johnson J, Boess F, Bendik I, Weber P, Hunziker W, et al: Phytanic acid, a natural peroxisome proliferator-activated receptor (PPAR) agonist, regulates glucose metabolism in rat primary hepatocytes. FASEB J 2002, 16:718-720.

32. Kitareewan S, Burka LT, Tomer KB, Parker CE, Deterding LJ, Stevens RD, et al: Phytol metabolites are circulating dietary factors that activate the nuclear receptor RXR. Mol Biol Cell 1996, 7:1153-1166.

33. Lemotte PK, Keidel S, Apfel CM: Phytanic acid is a retinoid X receptor ligand. Eur J Biochem 1996, 236:328-333.

34. McCarty MF: The chlorophyll metabolite phytanic acid is a natural rexinoid-potential for treatment and prevention of diabetes. Med Hypotheses 2001, 56:217-219.

35. Wolk A, Vessby B, Ljung H, Barrefors P: Evaluation of a biological marker of dairy fat intake. Am J Clin Nutr 1998, 68:291-295.

36. Wolk A, Furuheim M, Vessby B: Fatty acid composition of adipose tissue and serum lipids are valid biological markers of dairy fat intake in men. J Nutr 2001, 131:828-833.

37. Smedman AE, Gustafsson IB, Berglund LG, Vessby BO: Pentadecanoic acid in serum as a marker for intake of milk fat: relations between intake of milk fat and metabolic risk factors. Am J Clin Nutr 1999, 69:22-29.

38. Tholstrup T, Hellgren LI, Petersen M, Basu S, Straarup EM, Schnohr P, et al: A solid dietary fat containing fish oil redistributes lipoprotein subclasses without increasing oxidative stress in men. J Nutr 2004, 134:1051-1057.

39. Folch J, Lees M, Stanley GHS: A simple method for the isolation and purification of total lipids from animal tissues. J Biol Chem 1957, 226:497-509.

40. World Health Organization Study Group: Diabetes mellitus: Report of a WHO Study Group. Geneva: World Health Organization; 1985:99.

41. Tholstrup T, Sandstrom B, Hermansen JE, Holmer G: Effect of modified dairy fat on postprandial and fasting plasma lipids and lipoproteins in healthy young men. Lipids 1998, 33:11-21.

42. Noakes M, Nestel PJ, Clifton PM: Modifying the fatty acid profile of dairy products through feedlot technology lowers plasma cholesterol of humans consuming the products. Am J Clin Nutr 1996, 63:42-46.

43. Katan MB, Zock PL, Mensink RP: Effects of fats and fatty acids on blood lipids in humans: an overview. Am J Clin Nutr 1994, 60:1017S-1022S. 
44. Mensink RP, Zock PL, Kester AD, Katan MB: Effects of dietary fatty acids and carbohydrates on the ratio of serum total to HDL cholesterol and on serum lipids and apolipoproteins: a meta-analysis of 60 controlled trials. Am J Clin Nutr 2003, 77:1146-1155.

45. Poppitt SD, Keogh GF, Mulvey TB, McArdle BH, MacGibbon AK, Cooper GJ: Lipid-lowering effects of a modified butter-fat: a controlled intervention trial in healthy men. Eur J Clin Nutr 2002, 56:64-71.

46. Tholstrup T, Raff M, Basu S, Nonboe P, Sejrsen K, Straarup EM: Effects of butter high in ruminant trans and monounsaturated fatty acids on lipoproteins, incorporation of fatty acids into lipid classes, plasma C-reactive protein, oxidative stress, hemostatic variables, and insulin in healthy young men. Am J Clin Nutr 2006, 83:237-243.

47. Motard-Belanger A, Charest A, Grenier G, Paquin P, Chouinard Y, Lemieux S, et al: Study of the effect of trans fatty acids from ruminants on blood lipids and other risk factors for cardiovascular disease. Am J Clin Nutr 2008, 87:593-599.

48. Chardigny JM, Destaillats F, Malpuech-Brugere C, Moulin J, Bauman DE, Lock $\mathrm{AL}$, et al: Do trans fatty acids from industrially produced sources and from natural sources have the same effect on cardiovascular disease risk factors in healthy subjects? Results of the trans Fatty Acids Collaboration (TRANSFACT) study. Am J Clin Nutr 2008, 87:558-566.

49. McLeod RS, LeBlanc AM, Langille MA, Mitchell PL, Currie DL: Conjugated linoleic acids, atherosclerosis, and hepatic very-low-density lipoprotein metabolism. Am J Clin Nutr 2004, 79:11695-1174S.

50. Nicolosi RJ, Rogers EJ, Kritchevsky D, Scimeca JA, Huth PJ: Dietary conjugated linoleic acid reduces plasma lipoproteins and early aortic atherosclerosis in hypercholesterolemic hamsters. Artery 1997, 22:266-277.

51. Werner LB, Hellgren LI, Raff M, Jensen SK, Petersen RA, Drachmann T, et al: Effect of dairy fat on plasma phytanic acid in healthy volunteers - a randomized controlled study. Lipids Health Dis 2011, 10:95.

52. Neve BP, Fruchart JC, Staels B: Role of the peroxisome proliferatoractivated receptors (PPAR) in atherosclerosis. Biochem Pharmacol 2000, 60:1245-1250.

53. Mukherjee R, Davies PJ, Crombie DL, Bischoff ED, Cesario RM, Jow L, et al: Sensitization of diabetic and obese mice to insulin by retinoid $X$ receptor agonists. Nature 1997, 386:407-410

doi:10.1186/1476-511X-12-99

Cite this article as: Werner et al:: Effects of butter from mountainpasture grazing cows on risk markers of the metabolic syndrome compared with conventional Danish butter: a randomized controlled study. Lipids in Health and Disease 2013 12:99.

\section{Submit your next manuscript to BioMed Central and take full advantage of:}

- Convenient online submission

- Thorough peer review

- No space constraints or color figure charges

- Immediate publication on acceptance

- Inclusion in PubMed, CAS, Scopus and Google Scholar

- Research which is freely available for redistribution 